While wanton destruction has occurred, I believe it is the noise of the fishing boats constantly roaring past for two weeks that contributes most to the initial desertion. The fishing crews do not usually remain in the area after fishing operations have ceased, which is usually about the third week of June. It is at this time that the pelicans can re-nest, as they have done this year. It is quite likely that some fishermen did visit the island to gather eggs to eat, for this is a common practice all over northern Saskatchewan. I found no campfires on the island and no bird carcasses. I assume that the gulls and terns began laying eggs before the arrival of the fishermen, and had incubated them to a point where few were taken for food by the natives. Once a plainly visible embryo is formed most natives will not collect the eggs for eating purposes. The pelicans probably had a head start also, but the continuous activity may have disturbed them off their nests long enough and often enough to allow the many gulls to swoop in and rob most of the eggs.

I estimated that there were present on the island 1500 gulls, 500 pelicans, and 1000 common terns (all adults). Other species seen on or near the island were: Three male White-winged Scoters, one Franklin's Gull and one Spotted Sandpiper with a nest (four eggs) .

I see no way to avoid disturbing the pelicans so long as the fishing operations base remains on the adjacent island, which, as far as fishing is concerned, is an ideal location for the camp. On the other hand the pelicans must be afforded the full protection of the law. Periodic checks of the pelican colony after the fishing operation is completed should be made to determine nesting or renesting success. If it is found that the delay in nesting caused by fishing activity disturbances does not allow sufficient time for the successful rearing of young pelicans and if relocation of the fishing camp is not feasible, then other solutions to the conflict between the colonial birds and fishing interests should be considered.

\section{NEED FOR \\ PELICAN PROTECTION}

by C. Stuart Houston

836 University Drive, Saskatoon

Because of Ralph Carson's note "Destruction of colonial birds on an island on Suggi Lake," Blue Jay XXIV, p. 96-97, June 1966, I am adding the following notes some of which were published in Audubon Field Notes 18:515, October, 1964. On July 1, 1964 my wife and I chartered a plane from Nipawin to Suggi Lake. This was just 15 days afer Carson's trip which was reported in the last Blue Jay. On the long narrow rocky islet there were 466 White Pelican nests, 462 with eggs and the remainder with newly hatched young less than two days old. There were 53 Doublecrested Cormorant nests, all with eggs.

Our pilot, Ed Leclair, told us that Indians had been fishing commercially on this lake from May 13 to May 30. Presumably all original nests on the island were destroyed at that time and the birds had renested. By July 1 the young of the year should have been old enough to band so I wondered if the young would mature sufficiently to be able to make the fall migration.

I agree with Ralph Carson concerning the need for protecting the White Pelican before it is too late. The fishing operations of Suggi Lake is a relatively recent development which could soon sadly reduce the pelican population there. The White Pelican population is threatened elsewhere in Saskatchewan too. At Redberry Lake mid-day visits from increasing numbers of boaters who do not know that a short exposure to direct sun may kill a young pelican, threatens the pelicans though the Canadian Wildlife Service signs seem to have helped a lot. On Old Wives Lake the decreasing size of the pelican colony may be related to the use of toxic chemicals on farmlands draining into one of their main feeding areas-Thompson Lake. 